\title{
Erratum to: Fatty Acid Binding Site of Mitochondrial Uncoupling Protein UCP2 as Probed by EPR Spectroscopy of Spin-labeled Fatty Acids
}

\author{
N. Raju • T. Špaček • J. Ježek • I. M. Caminiti • \\ F. Leinisch $\cdot$ K. Hideg $\cdot$ P. Ježek $\cdot$ W. E. Trommer
}

Published online: 3 June 2010

(C) Springer 2010

Erratum to: Appl Magn Reson 30:373-383 (2006) DOI 10.1007/BF03166207

Peaks denoting $\mathrm{h}_{+1}$ and $\mathrm{h}_{-1}$ in the EPR spectra of spin-labeled fatty acids as shown in Figs. 2-7 are partially due to anisotropic motion in the large liposomes formed by $\mathrm{C}_{12} \mathrm{E}_{9}$ detergent solutions and even depend to some extent on polarity, ionic strength and the content of organic solvents herein as can be seen in the absence of any protein as described recently in "EPR Spectra of Spin-labeled Fatty Acids in Detergent Solutions: "Immobilized Species" in the Absence of Protein" by S. Kuntz, F. Leinisch, K. Hideg, W.E. Trommer, Appl Magn Reson 37, 455-461 (2010). Hence, our previous interpretation of these peaks as protein-bound fatty acids is only qualitatively correct, not quantitatively.

The online version of the original article can be found under doi:10.1007/BF03166207.

N. Raju · I. M. Caminiti · F. Leinisch · W. E. Trommer $(\bowtie)$

Department of Chemistry, Technical University of Kaiserslautern, Kaiserslautern, Germany

e-mail: trommer@rhrk.uni-kl.de

T. Špaček · J. Ježek · P. Ježek

Department of Membrane Transport Biophysics, Institute of Physiology,

Academy of Sciences of the Czech Republic, Prague, Czech Republic

K. Hideg

Institute of Organic and Medicinal Chemistry, University of Pécs, Pécs, Hungary 